\title{
PIONEERS OF CLERICAL FASCISM? MYTHICAL LANGUAGE OF REVOLUTIONARY POLITICAL CATHOLICISM IN SLOVAKIA AND VISIONS OF A "NEW NATION"1
}

\author{
Anton Hruboň
}

DOI: 10.17846/CL.2021.14.1.131-145

\begin{abstract}
HRUBOŇ, Anton. Pioneers of Clerical Fascism? Mythical Language of Revolutionary Political Catholicism in Slovakia and Visions of a "New Nation". Clerical fascism is among the vaguest and most corrupted terms in the political lexicon. As a result of abuse by the Communist regime for political purposes, it became an ideological label and insult after 1948. The present study attempts to revive this devalued term over the background of an analysis of the political language and ideology of Rodobrana, considered the first fascist movement in Slovakia (1923 - 1929). The study defines clerofascist ideology as a system of opinions, ideas and worldviews, functionally combining clericalism and fascism into a coherent worldview. The presented case study proves that, although clerical fascism has never formed the basis of any European regime, several variously significant political movements, including the Slovak Rodobrana, met its definition criteria. After outlining the methodology and general continental European context of the issue, the study analyses the forms of militarization of Catholicism in Slovakia after 1918, the formation of the concept of mystical ultra-nation, as well as the Rodobrana's vision of establishing a new religious community. The paper pays special attention to the work performed by the myth of purity in the political language of the Rodobrana, the political instrumentalization of Christ and his sacred blood in the context of creating the "revived nation".
\end{abstract}

Keywords: clerical fascism, Blood of Christ, Rodobrana, Hlinka's Slovak People's Party, Vojtech Tuka, Slovak fascism, political mysticism, mythic language

\section{Clerical fascism - between an ideological label and an analytical tool}

The term clerical fascism provokes rather passionate reactions in the Slovak milieu. In general, it is considered a product of post-1948 Marxist-Leninist historiography, which attempted to embed the Church and fascism in a mutually compromising correlation, thus killing two birds with one stone, so to speak. Despite some efforts to give it scientific weight (Sirácky 1955), MarxistLeninist historiography used the term very vaguely, as an ideological weapon against the enemies of the Communist regime, with the result that the term was perceived as an empty label for many

1 This work was supported by the Slovak Research and Development Agency under the Contract no. APVV19-0358. The study is also an outcome of the KEGA project no. 002UMB-4/2019 Kultúrne kódy „Novej Európy" na Slovensku v rokoch 1938 - 1945 v medzinárodnej komparativnej perspektíve (Cultural codes of the "New Europe" in Slovakia 1938 - 1945 in an international comparative perspective). Basic research was supported by the Fondation pour la Mémoire de la Shoah (Paris) as part of the project Quest for Cultural Roots of Holocaust in Slovakia: The Making of Hlinka's Slovak People's Party's Anti-Semitic Ideology (1890s 1920s) from a Transnational Perspective and Its Foreign Inspirations. 
years after November 1989. The first attempt to revive the term clerical fascism as an analytical tool for defining the specific synthesis of Christian teachings (of any denomination) and fascist ideology was presented by historian Miloslav Szabó in his monograph Klérofašisti (Clerical Fascists, Szabó 2019). As Szabó noted in his previous study, while many historians are tempted to apply this term to the regimes of entire states (Austria, Slovakia, Croatia etc.), studies of national manifestations of clerical fascism should instead focus on fascistization from below by individuals, such as clergy, theologians, Catholic intellectuals, journalists and participants in intellectual fora, who - with their radicalised perceptions of religion - had the potential to influence other people's thinking and actions directly (Szabó 2017, 683). For a regime to be called "fully fascist", the Church would have to control its social institutions (or directly rule over them) and introduce a form of "secular theocracy" under ecclesiastical supervision. This, however, never happened in any country. Not even did the Slovak State's Hlinka’s Slovak People’s Party's (Hlinkova slovenská ludová strana - HSL'S) regime in 1939 - 1945 become clerical-fascist in terms of a functional connection between Catholicism and National Socialism, despite Štefan Polakovič and Ludovít Zachar's efforts (Polakovič 1940, Zachar 1940) to formulate a nationally specific ideology of Slovak national socialism. Their efforts were eventually reduced to unavailing apologetics alleging the compatibility of National Socialism with Catholic doctrines and papal encyclicals.

The British political theoretician Roger Griffin, currently the author of the most respected theory of fascism, has also emphasized the impossibility of correlating fascism and Christianity in the context of political regimes. Like Szabó, Griffin asserts that in a historical context the term clerical fascism can correctly be used only with reference to individual attempts to confer a political (fascist) dimension to religion, either by succumbing to the redemptive quality of fascism ("fascism as a secular means for the edification of faith") or, more radically, by an intuitive or targeted erasure of differences between the fascist and the Christian ideas of rebirth, both of which constitute central myths in their respective ideologies (see Griffin 2008). This perception of the relations between fascism and Christianity results from the fact that in the first half of the 20th century (but also in the postmodern period), fascism and Christianity had common enemies, embodied in particular by liberals and socialists, which made many believe that the political victory of fascism would lead to the elimination of the greatest rivals of Christian traditionalism. The convergence of Christianity and fascism was also facilitated by an essentially similar project of palingenesis, framed by a "spiritual revival", and the firm belief that fascist movements and ideas were the best possible political means for the protection and promotion of religious interests (Pollard 2007, 435, 443; Costa Pinto 2017, 3-41).

At the turn of the 20th century, a number of philosophers and political theorists contemplated the need to create a model for a new type of politics - a kind of political religion or sacralised politics (Gentile 2008). They believed that the strict boundaries separating the sphere of politics from that of organized religion (the Church) had to be erased, as they did not reflect the fast pace of modernity and could not adequately react to its challenges. French thinker Georges Sorel, the founder of anarcho-syndicalism who later directly influenced Benito Mussolini, emphasized in his teachings the significance of myth as a key factor in mobilizing the masses (Sternhell 1994, 152-159). The mobilizing potential of myth also inspired Alfred Rosenberg, one of the principal ideologists of the National Socialist German Workers' Party (NSDAP). Influenced by "fathers" of modern racism Arthur de Gobineau and Houston S. Chamberlain, Rosenberg emphasized in his characteristically titled work Der Mythus des 20. Jahrhunderts the need to raise religion and politics to a new level by uniting them into a political movement imitating the Church hierarchy, thus creating a new myth in the nation that would awaken its racial consciousness and make the nation devote itself entirely to the mythical ideal - the cult of pure Aryan blood transcending all other values (Gregor 2015, 270). While Rosenberg's theories, conceived gradually from 1917 
on, did not provide answers to practical questions concerning the functioning of the German Volksgemeinschaft under the leadership of Hitler's NSDAP, his blood myth framed the spiritual world of the National Socialist regime until the very end. Rosenberg's concept comprised a certain extension to National Socialist thought regarding the categories of Aryan purity and constituted the basic framework for a new type of society, which European fascism, not only in its German national permutation, sought to achieve. Despite employing religious concepts and indirectly affecting a number of nationalist and fascist movements, as well as other movements flirting with fascism (including the HSL'S), Rosenberg's concept was not essentially theistic. His myth borrowed from Christian faiths only their allegorical images, not their teachings (Gregor 2015, 271; see also Szabó 2005). For this reason, it cannot be categorised as clerical fascism.

However, efforts to establish clerical fascist ideology as a coherent system of opinions, ideas and worldviews did appear in Europe in both the interwar period and during the Second World War. It is also important to note that they were not marginal movements. Perhaps the most typical example of an attempted fusion of Christianity and fascism was the Romanian Legion of the Archangel Michael (Legiunea Arhanghelului Mihail), also known as the Legionary Movement (Mişcarea Legionară) or Iron Guard (Garda di fier). The ideology of the Legionary Movement incorporated the ideas of Messianic nationalism, national and spiritual rebirth, regeneration, martyrdom, the death cult, and saints keeping watch over legionaries from the heavens. An important part of this ideology was the fetishization of the "political army" and the values of militarism, which were necessary in the process of the nation's spiritual revival. Followers of the charismatic leader Corneliu Codreanu believed themselves to be a divine instrument on the path to the nation's salvation, which the legionaries, after their political victory, would tear from the hands of the "Jewish Bolsheviks". They also believed that their aim of achieving an all-embracing palingenesis was blessed by God, whom they worshipped at their conventions and meetings in an array of rituals derived from the rite of the Orthodox Church (including the iconization of the movement's leaders and martyrs), or from earlier religious sources (e.g. thematization of the "crusader spirit" inspired by medieval knightly orders, various stylizations of the cross and swastika, consecration of the movement's martyrs etc.). This made the Legion a real bearer of a fascistized Christianity framed by ecumenical heroism (Iordachi 2010, 351-353). Codreanu himself did not have an ambition to create a new political platform. He argued that his movement only desired to unite into one whole all that was healthy in the Romanian milieu, and by means of a cultural-religious revolution impose the rule of omul nou (new man) in the country, thus establishing the rule of the creative synthesis of all positive achievements of the "Romanian spirit" (Payne 1997, 281), whose "believers" would gather in the spiritual unity of a legionary family (Schmitt 2016, 175-180), a kind of sacralised national community (see Maximová 2020, 198-199).

The link between a militant understanding of Christianity and fascism may also be traced in the ideology of the Belgian Rexist Party (Parti Rexiste). These young Belgian Catholics, led by the charismatic journalist Léon Degrelle and encouraged by Pius XI's encyclical Quas Primas, professed a radical understanding of Catholicism that departed from the conservative Catholic Party (Parti catholique), which had been part of the Belgian political landscape since 1869 (Conway 1993, 9-10). Degrelle, influenced by Maurras' movement Action français, which was considered the precursor of the modern European far right, unleashed a campaign in Belgium for the "return to purity and spiritual values", which he presented as a political crusade under the slogan Rex vaincra (The king will win), referring to Belgium's monarchist as well as Christian traditions. His Rexist movement, founded in 1935, soon lost its exclusively religious character and opened up to all Belgians. In his propaganda, Degrelle did not hesitate to openly attack the representatives of the Catholic Church and accuse them of corruption, proclaiming the need to purify society in order to create a healthy nation, to impose the rule of an authentic "dictatorship" 
of Christian dogmatic theology in public life, and to save the world by "heroes and saints who would carry out the reconquista” (Kedward 1969, 94-99; Griffin 1995, 205).

Another example of an intended unification of Christianity and the fascist visions of the world is the relatively small but - with respect to comparative fascist studies - very interesting Irish movement Architects of the Resurrection/Ailtirí na hAiséirghe (1942 - 1958). Its leader, Gearóid Ó Cuinneagáin, saw Ireland as an "apostolic state" which, building on the country's neutrality in World War II, would become a spiritual revivalist of the continent, corrupted by the sin of war, and restore the "Christian race" to its identity. Under the leadership of the Architects of the Resurrection, Ireland was to play a key role in the "Rechristianisation of Europe", a Europe infected by materialism, capitalism and communism, and, by combining traditionalist belief with modernity, bring a spiritual revival to the continent. Ó Cuinneagáin called for the instalment of a new order by spiritual revolution. In his "model Christian state", a completely new type of civilisation would be established, spreading its message like the medieval Irish missionaries. Despite distancing himself from Hitler and Mussolini, Ó Cuinneagáin advocated a complete transformation of society and state and the purification of language and culture from foreign influences. Unlike many clerical representatives of continental Europe, he held that Christian totalitarianism in the form of a leader state (Ceannaire Stáit) was fully compatible with the concept of the modern state and had the capacity to become a progressive synthesis of Christian teaching and the holistic-nationalist ideas of the state of "the third way" (Douglas 2009, 92-142).

Another figure who tried to establish a concept of Catholic, or clerical, fascism was the Czech intellectual Jan Scheinhost, the ideologist of the National Fascist Community (Národná obec fašistická). In the 1930s, the party even proclaimed an inseparable unity between the notions of Christianity and fascism (Drábik 2019, 423-424), though this was more a case of opportunistic pre-election calculation rather than the true intent of the movement's members, as many of them were atheists or religiously indifferent.

\section{The crisis of political Catholicism in Slovakia and the search for a new mobilization myth}

Much better conditions for the creation of a new type of political movement, combining clericalism and fascism, could be found in the more religious Slovak environment. Although the Catholic Hlinka's Slovak People’s Party (known until 1925 as Slovenská ludová strana/SL'S) was clearly the strongest political party in Slovakia from 1925 and throughout the interwar period, shortly after the establishment of the Czechoslovak Republic, Slovak political Catholicism was floundering. In the struggle for voters it was unable to keep pace with the Socialists, who - along with the Liberals - had constituted its major rivals since the end of the 19th century. The crisis of political Catholicism, which had emerged in the final decades of the dual Austro-Hungarian monarchy, resulted from its inability to compete against the expanding socialist movement, which proposed a solution to the most acute issue of the day - the social issue. The socialist programme, though utopian in nature, offered the new and numerous class of factory workers a recipe for solving the social injustices and conflicts as well as everyday issues of labourers in a rapidly modernizing world. The Catholic reaction to socialism's expansion in the form of papal encyclicals Rerum novarum (1891) and Constanti Hungarorum (1893) acted as a moral spur to Catholics in the Hungarian Kingdom and encouraged them to engage in increased social activization - organizing protective mechanisms such as Catholic conventions, clubs, associations and political parties with the intention to defend traditional Christian values against the secularisation advocated by socialists and liberals (see Štofaník 2017, 39-41). These initiatives, multiplied by the passing of 
secularisation laws in 1894, led not only to the 1895 foundation of the Hungarian Catholic Party (Néppárt) - the cradle of the Slovak People's Party (1905) - but also to the establishment of the National Christian-Socialist Party (Országos Keresztényszocialista Párt) in November 1907.

However, the social activization of the Church and the new political style were not always welcome in the ecclesiastical hierarchy. When Ottokár Prohászka, the Bishop of Székesfehérvár, proposed progressive land reforms and restrictions on the episcopate's capital and property in order to strengthen small farmers and agricultural cooperatives by leasing them Church land, he was derogatorily called a "modernist". Efforts to strengthen the position of lower social classes in other ways, for instance by establishing self-help cooperatives, rested on the shoulders of individual priests in the narrow confines of their parishes, villages or districts (Holec 2006, 160161). The practical implementation of Leo XIII's encyclicals into everyday life thus often remained merely declarative, and Christian socialism did not become part of the political practice of the Roman Catholic Church in Hungary as a whole.

The first general elections in Czechoslovakia in 1920 showed the tendency of Slovak political Catholicism to lag behind its rivals. The Slovak People's Party, listed together with the followers of Monsignor Jan Šrámek as the Czechoslovak People’s Party in Slovakia (Československá strana ludová na Slovensku), polled $17.55 \%$. This was surpassed not only by the Czechoslovak Social Democratic Workers' Party with $38.05 \%$ of votes, but also by the Slovak National and Agrarian Party with $18.05 \%$. The defeat of the 'Ludáks' by socialists in the ratio of 235389 to 510341 votes (Šuchová 2004, 554) was basically a debacle. The following parliamentary elections showed that the SLS, as the main representative of political Catholicism in Slovakia, was slowly gaining voters' confidence, but it also faced the formidable challenge of attracting young voters and retaining their support. The difficult social situation, the first global economic crisis $(1921$ - 1923), the complicated situation in the Czechoslovak labour market and the related massive emigration to the West inclined young voters towards left-wing radicalisation. The boundary between the SLS and the socialist (or communist) movement was thin, as the Catholic priest Jur Koza-Matejov noted: "The nation is inclined towards extremes, and those who turn away from the People's Party won't go back to the Czech or Czecho-Slovak parties, but will plunge themselves into communism. The path to communism leads through the People's Party!" (Letz 2006, 44). In the Slovak milieu, the SLS could at least build on the young generation's relatively strong religious sentiments, which - combined with traditional national and social themes - had the potential to become the cornerstone of a new wave of political mobilization. However, in the competitive atmosphere of dozens of political parties, incorporating these elements into a programme targeted at the young electorate without providing an attractive added value could be counterproductive.

\section{“Mobilization, brothers! The trumpet calls for Christ's soldiers! To arms!": The militarization of Catholicism and the mystical ultranation in the ideas of Vojtech Tuka}

One of the alternatives to the classic forms of political mobilization in the given situation was an untraditional cohesion of religiously framed traditionalism with the motif of a revolution, popular in Europe after World War I. The desire to fundamentally transform or completely dismantle the old "decadent" world and install a new social order was an essential building block of both the Bolshevik ideology and the newcomer on the scene - fascism. Although fascism as a cultural phenomenon had already infused part of European political culture in the last two decades of the 19th century (Sternhell 1994, 3), it was not until 1918 that it entered the political arena with a specific name and vision. 
Vojtech Tuka, the new face of the Slovak People's Party after 1918, noticed the mobilization potential of the energetic rhetoric that both communism and fascism used to address the public. In the party, Tuka was a figure of the younger middle generation (born 1880) without a past in the pre-1918 Slovak national movement, but with an exceptional intellectual capacity. During the monarchy, he was a professor of state and international law at the universities in Pécs and Bratislava. After entering the SL'S, he became the party's theoretical mastermind, working as its legal expert and from 1922 as the editor-in-chief of its daily paper Slovák, which allowed him to actively shape the party's ideology and propaganda. Tuka was known as a deeply religious Catholic with a radically antagonistic attitude to modernist movements (socialism, liberalism, secularism). Already at a young age, during his studies at the turn of the century, and influenced by his studies abroad in Paris and Berlin and his academic contacts with Karl Lueger's Vienna, he became convinced that the Hungarian Kingdom was in the midst of a culture war and the role of the Catholics was to "fortify our souls against attacks." As a university student he became deputy of a university organization called The Circle of Saint Emeric (Szent Imre kör), and later, as a lecturer in Pécs, he founded a group for law students which was associated with the nationwide Jesuit Catholic society Congregatio Mariana (Hertel 2005, 258; Lorman 2019, 189). Tuka continued to disseminate his views, which he outlined in his theoretical work A szabadság: politikai tanulmány (Tuka 1910), even after being forced to leave academia. Disengagement from the university environment enabled him to present the ideas articulated in his academic work in a new guise, dominated by Christian mysticism, addressing readers with a new militant rhetoric.

Tuka's booklet Kristovi bojovníci (Christ's Warriors) faithfully exemplifies the new mobilizing communication with the young Catholic generation. Published at his own expense, the booklet contains Tuka's speech given at the convention of Catholic students in Žilina on 14 August 1921 and reflects his way of thinking, which he a few years later transformed into the idea of a national manifestation of fascism framed by mysticism. In one of his first public speeches in Slovak, Tuka created the myth of "a thousand-year winter", followed at last by "spring" (Witt 2015, 319) and a new dawn for the nation. In the context of Slovak - but also Czechoslovak - cultural discourse after 1918, this was nothing original. Defining Slovakia against the historical Hungarian Kingdom, which represented a "dark night" (Tuka 1921, 1), was mainstream as part of the postwar anti-Magyarism supported by the Czechoslovak state. More interesting, however, are Tuka's references to "a new start" and "point zero", as well as his appeals to complete the "unfinished revolution" through the nation's spiritual revival. As Roger Griffin notes in his works (Griffin 1991, 26; Griffin 2016, 30, 39), all of these elements were part of the central utopian myth of fascist ideology, which had not yet been coherently formulated in the early 1920s, but manifested itself quite explicitly in the figures of speech through which the fascists communicated.

Tuka assigned this history-making mission to the Slovak youth, expecting them to start creating the narrative of an allegedly non-existent Slovak history. He encouraged them to actively work towards securing Slovaks their rightful place among the other sovereign nations of the world. In Kristovi bojovníci, reading between the lines reveals Tuka's clearly negative attitude to the Czechoslovak state and parliamentary democracy, which he did not acknowledge - at least when it came to their spirit. He appealed to the youth for the "conquest of their homeland", which is a literal translation of the Hungarian term honfoglalás, referring in the Hungarian narrative to the settlement of the Carpathian Basin by Old Hungarian tribes at the end of the 9th and beginning of the 10th centuries. However, Tuka did not use the term in its ethnogenetic sense; he used it in the cultural sense, calling Slovaks to conquer Slovakia culturally through a spiritual revolution that would change the country's spiritual character because, as he noted, the country was "ruled by sin" (Tuka 1921,3). He used this phrase to refer to the socialist, liberal and secular tendencies as well as the Hussite tradition, all of which he identified with the state idea of newly born Czechoslovakia. 
In such an environment, according to Tuka, the Slovak nation was clinically dead, and the only way to resurrect it was by means of a new political vanguard with a sacralised mission to save the nation and the majesty of its spirit (Tuka 1921, 3-4) and move it towards a new, brighter future.

Tuka embellished his language of mobilization with mystical metaphors: he positioned himself as the leader of "Christ's warriors", who he would lead under "Christ's banner" along an arduous path to conquer their homeland, drawing inspiration from nothing but Christ and Christianity, "the miraculous cure that makes nations eternally young" (Tuka 1921, 3). In Tuka's spiritual movement, still without organizational structure, there was no place for ordinary practicing Christians, but only for persons who - metaphorically reincarnated as knights of the Church would "stand up for faith on the public battlefield" and face "the corrupt" (Tuka 1921, 4), i.e. the socialists and liberals.

Another important thing about Tuka's "Christ's warriors", apart from the militant mysticism, is the scope of their identity. Tuka writes about commitment to confessional identity, which he understands as superior to national affiliation (Tuka 1921, 5). This inconspicuous remark may be a partial explanation of the author's well-known "national fickleness", but it also articulates an entirely new type of modernist man - a "guardsman of Christ" fighting for "a Slovakia imbued with the spirit of Christ" and "cleansed of dirt" (Tuka 1921, 6, 8). Tuka's political crusader is not a man in soutane, but an active campaigner for traditional values using the methods of modern political struggle, filled with vitality, with a clear moral code and a strong motivation to contribute through his holy struggle to the revival of Slovakia and the Slovak nation.

It is hard to say whether Tuka, with his concept of an ultranation under threat, but intent on waging a culture war and ready to defend its spiritual values, was consciously preparing the groundwork of a new political project or merely performing an intellectual exercise. In any case, the ideas that Tuka outlined in Christ's Warriors determined the main characteristics of the new national community, which he soon elaborated on, theoretically and practically, in a new political and paramilitary organization in Czechoslovakia - the Rodobrana of the Slovak People's Party.

\section{The Rodobrana as a platform for a new national sacral community}

When on 31 January 1923 SLS chairman Andrej Hlinka signed the Guidance for Organizers of Meetings and Festivities, which had been approved by both the administrative committee and the party's group of senators and members of parliament, he could hardly know that he was issuing a birth certificate to the mother of Slovak revolutionary fascism. The Rodobrana, which had officially been established to protect speakers during the SLS meetings, was suspended due to its members' participation in riots and street fighting on 30 August 1923 (Čaplovič 2001, 88). Thus, after a short seven-month period focused on building an organizational structure and acquiring a member base across Slovakia's various regions, the Rodobrana's members had to be temporarily redistributed among other organizations (e.g. the gymnastics clubs Orol and Omladina). These organizations under SL'S influence kept them physically and mentally fit while the members maintained their old ties and were ready to renew their activities once they were decriminalized. Shortly before the Rodobrana was renewed in 1925/1926, it had around 20,000 male members, formally still underground (Strnisko 2016, 115).

The large member base amounted to a reservoir of force which could be trained not only physically but also politically and ideologically once the ban was lifted. The Rodobrana's key figure was Vojtech Tuka, who in 1926 started to implement his earlier visions of mystical politics and elevated the Rodobrana, as his "spiritual child", from a fighting club imitating Mussolini's squadristi to politically conscious revolutionary fascists. 
From early on, the Rodobrana did not try to conceal its sympathies with Italian fascism. This was demonstrated by their imitating the "politics of the fist" which - like in Italy - was directed mainly at socialists. The Rodobrana was also characterised by other semantic elements referring to the spiritual bond with Il Duce's revolutionaries (e.g. wearing a black shirt, saluting with an extended right arm). In 1923 - 1925, however, the Rodobrana members did not profess any firmly defined ideology, with the exception of the principles of their own so-called Ten Commandments (Desatoro prikázani). Although the title alluded to the movement's Christian character, the commandments themselves did not make any connection between Catholicism, professed both by the SLS and the Rodobrana, and fascism (Slovak National Archives, Police Directorate Bratislava, box 236), nor did they contain any palingenetic slogans (such as "save/revive the nation" etc.; see Gardista, 30. 1. 1944, 3). The transformation of the Rodobrana into a movement whose ideology combined militantly perceived Christianity and revolutionary fascism started in early 1926. It was related to the relegalization of the Rodobrana's activity, its increased confidence after the HSLS victory in the 1925 parliamentary elections in Slovakia, and the Italian National Fascist Party's (Partito Nazionale Fascista) suppression of the opposition, which resulted in the passage of the so-called "fascist laws" (leggi fascistissime) in 1925/1926, strengthening the totalitarian system in Italy and seizing control of the state.

Much of this sentiment could already be felt in the article published in the 1926 New Year's issue of Slovák by Alexander Mach, the Rodobrana's organizer and Tuka's "right-hand man" who would later become minister of interior of the wartime Slovak State and head commander of the fascist militia, the Hlinka Guard (Hlinkova garda). In his article, Mach addressed the Rodobrana with militant rhetoric and mentioned the movement's new programme for 1926: "Hostile hatred has forced a sabre into our hands, and Love won't allow us - the Rodobrana - to toss it aside until Love tears it from our hands, because the victory of Love or - come what may - the path towards it is: the sword Christ has brought us for defence. Love and Sword!" In the text, which is interwoven with biblical motifs (Calvary, Christ, the blood of martyrs, devout love for the truth), Mach identifies the reason why the Rodobrana needed to be restored: "Just as tyranny is the Mother of Revolution, also has our Rodobrana arisen from the viscera of Mother Earth, tortured by the cruel blows of a murderous hand [...]. The Rodobrana was born of the hidden depths of Slovak mountains, villages and hearts [...]. Once the root causes of evil, wrong, injustice and the whole deadly system have been eliminated, the Rodobrana of today's programme will no longer be needed" (Mach 1926, 4).

The magical framework of Mach's esoteric language, connecting Christian mysticism with political revolutionism, became the basis of the Rodobrana's new communication strategy. After becoming an integral part of the HSL'S in September 1926 (Čaplovič 2001, 93), the organization gained legal protection against state authorities, which was confirmed by HSLS's entering the government in January 1927. The Rodobrana's organizers could thus continue elaborating its ideological profile.

As the Rodobrana's founder, Vojtech Tuka played a key role in the formation of the movement's complex ideology. Tuka saw the Rodobrana as a kind of laboratory for cloning a new type of movement which would serve as a platform for the creation of a qualitatively new nation, instilled with values cleansed of socialist-liberal "decadence". Based on the results of the 1925 parliamentary elections, he assumed that the HSL'S would become the leading force of the national front, which would restore Slovakia to its traditional values, but at the same time would not reject the political modernism represented by the energetic new stream in European politics. Tuka drafted a special ideological manual for the Rodobrana with the characteristic title The Rodobrana Catechism (Rodobranecký katechizmus, 1928), summarizing the movement's founding principles. In 58 questions and answers, the manual described the movement's activity as an existential struggle for "language, freedom, 
bread, schools, churches and all the spiritual and material wealth of the Slovak race", while defining "the Nation" (written with a capital N) as a community bound not by ethnicity or faith, but by blood (Rodobranecký katechizmus 1928, unpaged). Tuka thus expanded on the reflections he had expressed in the booklet Reverence for the Holy Blood of Christ (Úcta svätej krvi Kristovej, 1925). Although the booklet is not directly associated with the Rodobrana, the thoughts expressed therein fully reflect Tuka's understanding of the nation as a blood brotherhood, which he also implemented into the Rodobrana's ideology after 1926. In the booklet, Tuka specified his earlier calls for mystical reverence of Christian relics and connected them to the Benedictine monastery in Svätý Beňadik (present-day Hronský Beňadik), which housed the Veil of Saint Veronica, containing drops of Christ's blood, a present from Pope Paul II to King of Hungary Matthias Corvinus from 1483. Tuka dubbed this relic "the Slovak Holy Grail", elevating it to an object uniting the national and the Christian. Typical of the fervent style that he employed to impassion the reader with mystical Catholicism were figures of speech in which he compared venerators of relics to earthly soldiers fighting for the higher goals of the universal church. Terms such as "knights of the Slovak Grail", "the new regiment" and "the banner of Christ's army" (Tuka 1925, 3-4) clearly indicate the instrumentalization of Christian relics for secular needs, which was confirmed by the ideological framework of the restored Rodobrana, directly associated with Tuka's ideas, soon after the booklet's publication.

Blood, thematised in the booklet under The Litanies of the Holy Blood of Christ, acquired a double meaning in the Rodobrana's ideology. Blood was not only the sacred essence of the suffering Jesus Christ, the holiest being of the Christian faith, and the symbol of this suffering, but also a symbol of purgation, sanctifying its venerators (the Rodobrana) and their acts (see Schury $2004,54)$. In a figurative sense, the bloody sacrifice that the Rodobrana would make in the struggle with their political opponents was a means of sanctifying the movement and its goal - a means of sacralising the struggle for a "purified Slovakia". Thus the practiced reverence for the blood of Christ captured in the Beňadik relic was a means of the nation's spiritual renaissance ("spiritual resurrection") and its political awakening, which, joined in a mystical unity, would create a new nation. In the afterword to Tuka's booklet, Beňadik priest Matej Buček expressed his wish that "the reverence for the holiest Blood renew the blood of our nation, so exposed to great temptations, and that of our youth, and that the desire of the author of this work to spread the reverence for the holy Blood among the wide layers of our religious nation be fulfilled!” (Buček 1925, 20). Shortly after the publication of Tuka's Reverence, the fulfilment of Buček's wishes started to be reflected in the Rodobrana's political culture.

From 1926 onwards, the Rodobrana increasingly visited Catholic pilgrimage sites around Slovakia, where, in addition to religious customs, i.e. performing devotions, it often arranged parades, oath-taking and consecrations of Rodobrana flags. One such place, in addition to Mariatál and Šaštín, was Svätý Beňadik, which became central venue of worship for the cult of the blood of Christ. The Rodobrana established a cultic site around the Beňadik relic, a place associated with rituals resembling those that were practised in neopaganistic form by the NSDAP, among others (see Goodrick-Clarke 1985). The first such monumental "political mass" was organized by the Rodobrana on the occasion of Pentecost on 22 - 23 May 1926. During this meeting of the movement's delegates, the Rodobrana's commanders gathered at the Beňadik monastery, where "grail knight ceremonies" took place, followed next day by a collective oath-taking of three thousand Rodobrana members, an oath that "consecrated them to the Slovak nation and the Christian idea." Also, Tuka delivered a speech emphasizing the indissoluble unity of the Slovak and Christian identities, arguing that their syncretism was the only path to victory in the fight against "evil, injustice, immorality, corruption and misery." The "warrior of Christ" glorified by Tuka was to become the chosen one, whose activities in the Rodobrana's black army would ensure that "our Slovak nation wakes up from its national slumber" (Slovák, 26. 5. 1926, 2). At the gathering in 
Mariatál on 25 July 1926, one speaker even called the Rodobrana "modern Slovak Boanergeses" (Slovák, 27. 7. 1926, 4), Sons of Thunder, as Christ named his apostle James and his younger brother John. The motif of a thunderbolt was not unique among the allegories of fascist movements - as a symbol of striking force, of both destructive and creative power, it was also employed, for instance, by the British Union of Fascists and the tiny Slovak fascist Christian Workers' and Peasants' Civic Party (Drábik 2014, 260; Hruboň 2015, 136).

Images of the nation's salvation by means of sacralised politics also characterised every single issue of Rodobrana, the first notable periodical with a fascist focus in Slovakia (1926 - 1929). Its editor and author of many of its articles, Alexander Mach, was known for his exalted language and, as a former theologian of the Esztergom seminary, often used theologian vocabulary in Rodobrana propaganda, seeking to give his texts a thunderous mobilizing subtext. In the very first issue, published on 25 July 1926, he wrote of sanguis martyrum, the blood of martyrs, who laid the movement's foundations "in the soil soaked with blood, blood whipped out of the nation." The hot blood of martyrs, "born from their suffering", was the magical fire that would again ignite mystical enthusiasm among the Rodobrana's members, hiding underground, so that their blessed activities would heal "the many wounds, the bleeding, the pus and stench" in the Czechoslovak Republic, and "rid the nation's body of ulcers and insects, fraud and affairs, so as to save the nation's morals and wealth and resurrect its consciousness" (Mach 1941, 294-295, 301). Mach described the Rodobrana as "the bearers of sacred national and Christian principles" and as soldiers of the "fascist army" that would "cleanse public life, win freedom for Slovakia and rid the republic of the red leeches", as well as remove "the red tyrants of Prague, of Moscow and of the hooked nose." (Mach 1941, 291)

Besides their paeans to Mussolini's regime, which "uprooted the gallows with a strong hand and sowed a healthy seed in the Italian land" (Mach 1941, 292), the Rodobrana's language employed the motif of approaching cataclysm with expressive vocabulary from the category "between heaven and earth". Mach compared Slovakia to "a vast cemetery", the Hlinka Party's enemies to "the gates of hell", "the Antichrist", "the Devil" or "Beelzebub", and he referred to the movement's ideology as "the Truth" (Mach 1941, 301, 305). Mach believed that despite the disrupted social conditions, despite the fact that "our state resembles the Augean stables", there was hope for Slovakia. The Rodobrana, led by "people with clean hands", was to become the proverbial "broom" that "must mercilessly accomplish Hercules' task." The life of a Rodobrana member had to be clean as well, so that it would act as a model for everyone, as "the vanguard of culture" (Mach 1941, $305)$, i.e. a civilized alternative to the lifestyle of decadent people with "lower morals" that did not correspond to Christian ethics.

\section{Biological protoracism? Salvation through the "purified" Christ and blood}

Despite the sacred guise of the movement's (or, in a wider sense, the Hlinka Party's) political aims, declared in fascist rhetoric, the purificational framework of the Rodobrana's politicalreligious palingenesis would not have been sufficiently convincing for the target audience had its central cults - Jesus Christ and the Slovak nation - not also been objects of purification. From the perspective of the purificational ambitions of the openly antisemitic Rodobrana, the question of defining the Son of God and the essence of the national organism was of key importance. In the process of revolutionary purification, Slovakia clearly could not be restored to its most sacred Christian values by the spirit of a messiah of Jewish origin, and the object of this purification could not be the parts of the nation comprised of "parasites and obstructionists, hollow and hiding 
good-for-nothings", who, according to Mach, caused "direct harm to the nation" and had to be excluded from the ranks of the national community (Mach 1941, 305, 325).

Although the Rodobrana were deeply religious Catholics, Christ had a mostly symbolic meaning in the movement's ideology. During their rituals, members did not worship Christ as a divine entity, but rather venerated the values he represented in Christian mysticism: martyrdom and the highest sacrifice in his fight for the truth, leading to the world's salvation. Although the holy masses at the organization's meetings naturally did have a religious aspect, its members perceived them as a way of soliciting God's blessing for accomplishing their political objectives (as the periodical Rodobrana noted, during one pilgrimage in Mariatál, for instance, "the Rodobrana prayed contritely during the mass so that God would bless their efforts to improve the fortunes of Slovakia”; Rodobrana, 1. 8. 1926, 1; Slovák, 27. 7. 1926, 3).

The Rodobrana's propaganda did not refer to Christ's Jewish origin, and it borrowed only those aspects from his life that corresponded with the template of its sacralised politics. An important part of the movement's symbolism was a cross with a wreath of thorns (an allusion to Christ's crown of thorns, which he wore on the way to his crucifixion on Golgotha), which the Rodobrana members had embroidered on their black shirts and later wore in the form of a metal badge on the left chest of their clothing. The black shirt and the thorn-wreathed cross were combined to form "the robe of national resurrection", which the Rodobrana would wear on special days when "the nation is being cleansed of the filth of ulcers, parasites [...], when the nation arises from dust to appear before the face of Lord on the world stage" (Rodobrana, 1. 8. 1926, 1), i.e. during "political masses" and political events. It is interesting to note that despite the practiced reverence for the blood of Christ, the figure of Jesus was absent from the Rodobrana's symbols and visual propaganda. New Testament parables referring to his Jewishness were missing, and only his qualities as an "Aryan" hero were thematised (his revolutionary character, courage, martyrdom etc.). This was a necessary outcome of the fascistization of Catholicism as presented by the Rodobrana. Only this Aryan Christ could satisfy the Rodobrana's obsession with purity and its concept of a purified nation, born of a spiritual revolution under the patronage of imaginary sanctification by pure blood. In the allegorical process of national resurrection, the "pure blood" became the defining point of the new national community, which was bound by a spiritual bond as well as by blood. The Rodobrana used the blood bond to define themselves, and this was reflected not only in the organization's name (the Slovak word rod ("lineage", "bloodline") refers to a group of people with blood relations), but also in their oath: "I swear on the most precious holy blood that was shed for us, I swear that I shall always boldly protect the honour and freedom of the holy church, and that I shall work tirelessly for the spiritual and material wellbeing of my beloved Slovak nation, and fearlessly fight for its holy, God-given rights and freedom [...]. I shall be a loyal and obedient warrior of Christ. Even at times of greatest hardship and danger I shall act as God will tell me to, and following the Saviour's example I am ready to seal this oath in blood. So help me the blood of Christ!" (Slovák, 18. 9. 1926, 1).

Due to the lack of relevant sources it is hard to tell whether, or to what extent, the Rodobrana adopted the blood myth as their fundamental self-identifying factor. Hlinka's Slovak People's Party did not cultivate it as part of its political culture in the 1920s, and the eugenic movement in Slovakia and the Czech lands, employing the concept of a "perfect race", was more or less a matter of intellectual circles without echoes in the political sphere (see Šimůnek 2007). Legally speaking, Hlinka's Slovak People's Party did not fully adopt the biological understanding of the nation until the Jewish Code was passed on 9 September 1941 (Nižňanský 2016, 236). Culturally, however, it cherished the myth of the superior, racially pure and noble Slovak nation (anthropologically defined by "Slovak blood") as opposed to the "degenerated Jewry", at least from the mid-1930s. In the circumstances of the rising fascist "New Europe", which from the autumn of 1938 also 
included Slovakia, antisemitic discourse was treated in a completely new way, much different from, for instance, the antisemitic racism of Svetozár Hurban Vajanskýs earlier works (see Szabó 2014, 29-48). The main responsibility for disseminating this negative image lies with the generation of the young radicalised members of the HSLS, who were connected with the Rodobrana through both personal relationships and ideological bonds. The Rodobrana's ideas stayed with them even after its dissolution in 1929, and later had an indirect impact on the ideological framework of the renewed Rodobrana - the Hlinka Guard (Gardista, 28. 1. 1939, 7).

\section{The alma mater of Slovak clerical fascism? (Concluding reflections)}

For Catholics in Germany and Italy, the victory of fascism posed an instant threat to the authentic faith and its practice. They rightfully saw the religious worship of secular entities as an expression of modern neopaganism or, in the words of Luigi Sturzo, co-founder of the Italian People's Party (Partito Popolare Italiano) and coiner of the term "clerical fascism", an expression of collective idolatry, harming the existential future of Christianity (Gentile 2008, 103). Neither the HSLS nor the Rodobrana - unlike the NSDAP and the PNF - posed a direct threat to the traditional structure of the Catholic Church or its role in societal life. However, critical voices directed at the Rodobrana's efforts to unite clericalism and fascism were far from isolated. Opponents of the Rodobrana's political practice, such as HSL'S renegade Koza-Matejov, criticised its politicisation of church services and oaths "in the name and at the expense of Catholicism" (Slovák, 18. 9. 1926, 1; NA Praha, f. PMV, 225-1451-5), because they saw it as a form of blasphemy. At the same time they feared that the street rioting of the Rodobrana, in whose "political masses" Catholic priests participated by conducting the services directly or openly expressing support for the movement, would be associated with the Roman Catholic Church as a whole, which would harm its image of an independent and eternal institution.

With its coherent ideology, albeit unfinished due to the short existence of the movement, the Rodobrana offered an alternative vision of a new nation and its regenerated spirit, whose basic elements were the mythical ideas of generic fascism and mystical Catholicism understood in revolutionary terms. The attempt at their functional symbiosis - clerical fascism - was reflected in the movement's political language and practice, though none of its contemporaries articulated this. The Rodobrana's clerical fascism was an energetic answer to the spiritual emptiness and sense of peril that characterised political Catholicism in the first years of the Czechoslovak Republic, and gave its supporters hope of a new, politically engaged radical Catholicism, or the "saving of God" from secularisation and secular society. These tendencies occurred not only in Europe's Catholic cultural zone, but also in its Orthodox and Protestant counterparts (Pollard 2007, 443). In its Programme, published on the front page of the first issue of the movement's periodical, the Rodobrana explicitly subscribed to fascism and its main defining criteria (see Rodobrana, 26. 7. 1926, 1). The HSLS regime in turn subscribed to the Rodobrana - even during its own deepening crisis, when it emphasized that it could draw on the ideas and the virgin idealism of the Rodobrana's vanguard of Slovak fascism even in hard times, when Hitler's "New Europe" was falling apart (Gardista, 30. 1. 1944, 4). Although Tuka's construct of a new national community, formed from the Rodobrana, remained a utopia, some traits of its ideology, such as the cult of purity (or purification), the blood myth, the belief in the party's supernatural mission, and the instrumentalised religious motifs of propaganda did take root in the HSL'S's political thinking and were implemented into practice after the autumn of 1938. The movement's revolutionary mystical language, however, was only adopted by "lone wolves" such as priests Viliam Ries, Karol Körper and Vladimír Rolko (see Szabó 2019). 
The more conservative ideologists of the HSL'S regime, such as Štefan Polakovič, were not concerned with the Rodobrana's message. They preferred the path that Polakovič himself called "Christian totalitarianism" (Polakovič 1939, 118, and Münz 1994, 459-461; Pekár 2014), which despite the attractive name - he understood as a non-revolutionary Ständestaat after the model of Austria during the Dollfuss and Schuschnigg era (see Jeřábek 2004, 187-194). The "clerofascistization" of the regime was not achieved in the period from the summer of 1940 to the end of 1942 either, when Slovak politics was dominated by the revolutionary National Socialists, and political culture and public life in Slovakia were in the phase of revolutionary fascistization. In their plans to revive Slovak society, with the Hlinka Guard as a revolutionary instrument of power, Tuka and Mach, undoubtedly influenced by the German counsellors installed in Slovakia after the Salzburg Conference, did not employ mystical religious language as a driver of the nation's spiritual rebirth. The "Vaticanization" of the country in any form was undesirable for the Reich.

In the wartime Slovak Republic (1939 - 1945), clerical fascism did not become state ideology. Nevertheless, the views of its individual exponents, expressed in articles and in the speeches of radicalised priests and laymen, did contribute to the radicalisation of the attitudes and political convictions of ordinary members of Slovak society. The fact that the ideas and rituals of clerical fascism were not implemented into practice (perhaps with the exception of language and some of the Hlinka Guard's rituals related to the "sanctification of the blood of heroes") proved that the ideologies of fascist movements are not always strong enough to become the ideology of the regime - it they lose their revolutionary potential as soon as the monopoly of power is established, or they prove too impotent to provide a comprehensive recipe for governing the new purified society.

\section{REFERENCES}

\section{Archival sources}

Národní archiv v Prahe, f. Presidium ministerstva vnitra, k. 1451.

Slovenský národný archív v Bratislave, f. Policajné riaditel'stvo Bratislava, k. 236.

Gardista, 28. 1. 1939, 30. 1. 1944.

Mach, Šaňo [Alexander]. 1926. Láska a Boj. Novoročné Rodobrancom - Prečo sme a prečo musíme byt. In Slovák, 1. 1. 1926, 4.

Rodobrana, 26. 7. 1926, 1. 8. 1926.

Slovák, 26. 5. 1926, 27. 7. 1926, 18. 9. 1926.

\section{Secondary sources}

Buček, Matej. 1925. Perla Pohronia, Svätý Beňadik a jeho skrytý poklad. In Úcta svätej krvi Kristovej. Trnava, 10-20.

Čaplovič, Miloslav. 2001. Branné organizácie v Československu 1918 - 1939 (so zretelom na Slovensko). Bratislava.

Conway, Martin. 1993. Collaboration in Belgium: Leon Degrelle and the Rexist Movement, 1940 1944. New Haven.

Costa Pinto, António. 2017. Corporatism and 'organic representation' in European dictatorships. In Corporatism and Fascism. The Corporatist Wave in Europe. London - New York, 3-41. 
Douglas, Raymond M. 2009. Architects of the Resurrection: Ailtirí na hAisérghe and the fascist 'New Order' in Ireland. Dublin.

Drábik, Jakub. 2014. Mýtus o znovuzrození. Britská unie fašistů a její propaganda. Praha.

Drábik, Jakub. 2019. Fašizmus. Bratislava.

Gentile, Emilio. 2008. Politická náboženství: mezi demokracií a totalitarismem. Brno.

Goodrick-Clarke, Nicholas. 1985. The occult roots of Nazism: the Ariosophists of Austria and Germany 1890-1935. Wellingborough.

Gregor, A. James. 2015. Totalitarismus a politické náboženství. Intelektuální historie. Brno.

Griffin, Roger. 1991. The nature of fascism. London.

Griffin, Roger. 1995. Fascism. Oxford.

Griffin, Roger. 2008. The 'Holy Storm': 'Clerical Fascism' Through the Lens of Modernism.

In Totalitarian Movements and Political Religions 8/2, 213-227.

Griffin, Roger. 2016. Modernismus a fašismus. Pocit začátku za Mussoliniho a Hitlera. Praha.

Griffin, Roger. 2018. Fascism. Cambridge.

Holec, Roman. 2006. Úloha katolíckej cirkvi pri formovaní občianskej spoločnosti na Slovensku.

In Česko-slovenská historická ročenka 2006, 155-173.

Hruboň, Anton. 2015. „Blaho vlasti - zákon najvyšší!” Národná obec fašistická a Slovensko (1926 1938). Ružomberok.

Iordachi, Constantin. 2010. God's chosen warriors. Romantic palingenesis, militarism and fascism in modern Romania. In Iordachi, Constantin et al. Comparative Fascist Studies. New Perspectives. Abingdon, 316-357.

Jeřábek, Martin. 2004. Konec demokracie v Rakousku 1932 - 1938. Politické, hospodářské $a$ ideologické př́ćiny pádu demokacie. Praha.

Kedward, H. Roderick. 1969. Fascism in Western Europe 1900 - 1945. Glasgow.

Letz, Róbert. 2006. Hlinkova slovenská ludová strana (Pokus o syntetický pohlad). In Letz, Róbert - Bartlová, Alena, Mulík, Peter et al. Slovenská ludová strana v dejinách 1905 - 1945. Martin, 12-108.

Lorman, Thomas. 2019. The making of the Slovak People's Party: religion, nationalism and the culture war in early 20th century Europe. London - New York - Oxford - New Delhi - Sydney. Mach, Šaňo [Alexander]. 1941. Kurzívkovým tónom. Trnava.

Maximová, Jarmila. 2020. National Communities as the Space of Value Preservation and Transformation from the Perspective of Particularism and Universalism (The Issue of National and European Identity). In Konštantínove listy [Constantine's Letters] 13/1, 197-207.

Münz, Teodor. 1994. Náboženská filozofia na Slovensku v prvej polovici 20. storočia. In Filozofia XLIX/7, 403-481.

Nižňanský, Eduard. 2016. Politika antisemitizmu a holokaust na Slovensku $v$ rokoch 1938-1945. Banská Bystrica.

Payne, Stanley. 1997. A history of fascism, 1914 - 1945. Madison.

Pekár, Martin. 2014. Štátna ideológia a jej vplyv na charakter režimu. In Fiamová, Martina, Hlavinka, Ján, Schvarc, Michal et al. Slovenský štát 1939 - 1945. Predstavy a realita. Bratislava, 137-152.

Polakovič, Štefan. 1939. K základom slovenského štátu. Turčiansky sv. Martin.

Polakovič, Štefan. 1940. Slovenský národný socializmus. Ideové poznámky. Bratislava.

Pollard, John. 2007. 'Clerical fascism': Context, Overview and Conclusion. In Totalitarian Movements and Political Religions 8/2, 433-446.

Rodobranecký katechizmus. 1928. Bratislava.

Schmitt, Oliver Jens. 2016. Căpitan Codreanu. Aufstieg und Fall des rumänischen Faschistenführers. Wien 2016. 
Schury, Gudrun. 2004. Miazga života: kultúrne dejiny krvi. Bratislava.

Sirácky, Andrej. 1955. Klérofašistická ideológia ludáctva. Bratislava.

Sternhell, Zeev. 1994. The birth of fascist ideology: from cultural rebellion to political revolution. Princeton.

Strnisko, Igor. 2016. Slovenská Rodobrana $v$ druhej fáze pôsobenia (september 1923 - december 1925). In Kultúrne dejiny, supplementum, 2016, 97-116.

Szabó, Miloslav. 2005. Rasa a vôla. Alfred Rosenberg a Mýtus 20. storočia. Bratislava.

Szabó, Miloslav. 2014. Od slov k činom. Slovenské národné hnutie a antisemitizmus (1875 - 1922). Bratislava.

Szabó, Miloslav. 2017. „Klérofašizmus”? Katolicizmus a radikálna pravica v stredoeurópskom kontexte (1918 - 1945). In Historický časopis 65/4, 675-687.

Szabó, Miloslav. 2019. Klérofašisti. Slovenskí kňazi a pokušenie radikálnej politiky (1935 - 1945). Bratislava.

Šiminek, Michal. 2007. Eugenics, Social Genetics and Racial Hygiene: Plans for the Scientific Regulation of Human Heredity in the Czech Lands, 1900 - 1925. In Turda, Marius - Weindling Paul J. et al. Blood and Homeland. Eugenics and Racial Nationalism in Central and Southeast Europe. Budapest - New York, 145-166.

Štofaník, Jakub. 2017. Medzi krížom a kladivom. Recepcia sociálneho myslenia v katolíckej cirkvi v prvej polovici 20. storočia. Praha.

Šuchová, Xénia. 2004. Politický systém. In Zemko, Milan - Bystrický, Valerián et al. Slovensko v Československu (1918 - 1939). Bratislava, 545-616.

Tuka, Béla [Vojtech]. 1910. A szabadság. Politikai tanulmány. Budapest.

Tuka, Vojtech. 1921. Kristoví bojovníci. S. 1.

Tuka, Vojtech. 1925. Úcta svätej krvi Kristovej. Trnava.

Witt, Sabine. 2015. Nationalistische Intellektuele in der Slowakei 1918 - 1945: kulturelle Praxis zwischen Sakralisierung und Säkularisierung. Berlin.

Zachar, Ludovit. 1940. Katolicizmus a slovenský národný socializmus. Štátovedecká úvaha. Bratislava.

doc. PhDr. Anton Hruboň, PhD.

Matej Bel University in Banská Bystrica

Faculty of Political Science and International Relations

Department of Security Studies

Kuzmányho 1

97401 Banská Bystrica

Slovakia

anton.hrubon@umb.sk 